\title{
CHALLENGES IN THE FOURTH INDUSTRIAL REVOLUTION
}

\author{
Gabriela-Maria MAN \\ "Lucian Blaga" University, Sibiu, Romania \\ gabriela.man@ulbsibiu.ro \\ Mihaela MAN \\ "Lucian Blaga” University, Sibiu, Romania \\ mihaela.man@ulbsibiu.ro
}

\begin{abstract}
The beginning of the twenty-first century represents the beginning of the Fourth Industrial Revolution, which, unlike its predecessors, is characterized by great digitalization, higher connections between physical things and the virtual world, the development of genetics, artificial intelligence, hyper connectivity. These characteristics have generated many changes in the way work is performed. In order to meet these challenges, employees must increase their flexibility in the way they perceive work time, wages, tasks, workspace and so on. And, in an era of technology and digitalization, employees must keep their skills and knowledge, related to new technology, up to date. Several other aspects related to employability will be discussed in this article.
\end{abstract}

KEYWORDS: Fourth Industrial Revolution, flexibility, digitalization, employability

\section{Introduction}

The industrial revolution, from the end of the eighteenth century (Allen, 2011), was associated with increased diversity in work (Doll \& Vonderembse, 1991) and was, according to the specialists, the First Industrial Revolution. Since the eighteenth century, other industrial revolutions have followed (Park, 2017). It is now thought that we are at the beginning of the Fourth Industrial Revolution (Schwab, 2016). This latest revolution is shaped by digitization and information technology. Schwab (2016) points out that the changes shaping the twenty-first century and the Fourth Industrial Revolution are: at the physical level - the development of driverless cars, drones, 3D printing, robots, development of smart materials; at the digital level - the "internet of things", which refers to the chain between products-services-places, connections between physical things and the virtual world, remote monitoring and remote controlling, bitcoin, digital platforms etc.; and at the biological level - gene editing, the development of synthetic biology, the editing of living tissues, etc. (Schwab, 2016). During this revolution, the keywords that describe it best are hyper connectivity, hyper analysing, and digitalization (Park, 2017), a combination between real and virtual space and more interactions between man and artificial intelligence (Lee et al., 2018).

\section{Employability During the Fourth Industrial Revolution \\ In this context, it should not be a surprise that the knowledge, skills and abilities required by employers during the}


Fourth Industrial Revolution are different compared to the knowledge, skills and abilities required by the other three industrial revolutions. It is estimated that many jobs in the near future will be delegated to artificial intelligence (AI) or become automated (Frey \& Osborne, 2017). As a consequence of the changes that are expected, it is also estimated that roughly $35 \%$ of today's children, when adults, will have job types that exist today; the rest will have job types that do not yet exist (World Economic Forum, 2016).

In the context of the Fourth Industrial Revolution, dominated by massive changes in the way people work (World Economic Forum, 2018), questions may arise such as: what should an employee do to be employable?

\section{Flexible Perception of Work Arrangements and Work}

In order to increase employability, current and future employees need to be flexible in terms of work arrangements and to be flexible in the way they perceive work. Work arrangements, in many countries, have experienced changes when it comes to working time and guaranteed wages. Regular hours arrangements are decreasing, and non-standardized work forms are emerging (Aleksynska \& Muller, 2015; Eichhorst \& Tobsch, 2013; Alterman, Luckhaupt, Dahlhamer, Ward \& Calvert, 2013; Katz \& Krueger, 2016, 2017). There are even working arrangements between employees and employer where employers do not guarantee any working time and work. This type of arrangement is called a zero-hours contract (Datta, Giupponi \& Machin, 2018; Farina, Green \& McVicar, 2019). Other forms of non-standardized arrangements may allow a worker to be hired by a group of employers, or allow a single employer to hire two or more workers to fill a full-time job and so on (Eurofound, 2015).
At the same time, with the development of alternative forms of work such as portfolio work and crowd employment, changes in the way work is performed have emerged - a shift from having a job to having contracts with organizations, limited to specific problem solutions and limited to the provision of specific services (a project instead of a job) (Leighton \& Brown, 2013; Saxton, Oh \& Kishore, 2013).

Not only are working time and wages no longer standard, and are changing, the workspace is also changing. The standard workspace involves an office, factory and so on, but with the development of telework and New ICTs (such as cloud-based work), the "office" can be anywhere: in a coffee house, at home and so on (Messenger \& Gschwind, 2016). It is estimated that in the U.S. in 2014, $2.8 \%$ of employees used telework; while in the E.U., $7 \%$ of employees used telework at least a quarter of the time in 2005 (International Labour Organization, 2016). In the Fourth Industrial Revolution, the "office" can be on another continent (Schwab, 2016). Jobs that do not require face to face interaction may be performed by professionals located on another continent using technology to communicate with the employer (Baldwin, 2019).

Work relations are also different; greater diversity has emerged in the twentyfirst century and this diversity will be more visible in the future (Christian, Porter \& Moffitt, 2006; Prasad, Pringle \& Konrad, 2006). Women are more involved in paid work compared with women at the end of the twentieth century (Organization for Economic Cooperation and Development, 2010), even in traditionally male-dominated activities. Employees with different beliefs and backgrounds are often encountered in many organizations (Mazur, 2010), and cultural diversity is increasing due to increased migration. In many developed countries the rates of migration are high (United Nations, 2017), but cultural 
diversity may also increase due to a new form of migration: telemigrants. Telemigrants are employees working from another continent or country, and use technology to communicate with colleagues, clients and supervisors (Baldwin, 2019). Age diversity may also increase at work due to changes in retirement patterns that have become visible in recent years (Philips \& Siu, 2012). All of these sources of diversity require the development of social skills in order to perform job-related tasks.

\section{Technology Updates}

The increased number of crowd workers (Wobbe, 2016) - an employment arrangement where individuals solve problems and provide services for different organizations, mediated by online platforms (Brabham, 2008; Saxton et al., 2013); the increase in teleworkers (Baldwin, 2019), the development of the "internet of things" (Schwab, 2016), hyper connectivity, digitalization (Park, 2017), the increase in artificial intelligence and increase human/ machine interactions and machine/human interactions (Jarrahi, 2018; Wang, Khosla, Gargeya, Irshad \& Beck, 2016); all of these point to the fact that employees need to learn to work with technology but also need to constantly update their knowledge and skills regarding technology in order to increase their employability.

The need to adapt to technology is also supported by statistics that estimate that in future new professional roles will emerge, and many of them are related to the use of technology, for instance: AI and machine learning specialists, big data specialists, digital transformation specialists, new technology specialists, software and applications developers and analysts, information technology services specialists, etc. (World Economic Forum, 2018).

\section{Skills and Abilities}

According to Davies, Fidler and Gorbis (2011), in addition to the characteristics mentioned above, the following skills are required today and in the future: sensemaking skills (to be able to find meaning and insights), social abilities, novel and adaptive thinking (creative), cross-cultural competencies, computational thinking, new-media literacy, transdisciplinarity, virtual collaboration, cognitive load management (ability to select important information and ignore irrelevant information) (Davies et al., 2011). All of these skills are in contrast with the skills needed for repetitive and physical tasks; tasks that have a greater possibility to be replaced by robots and machines (Frey \& Osborne, 2017). High skill occupations have also increased (Acemoglu \& Autor, 2011). Statistics for 2018 reveal that persons with higher educational levels have higher rates of employment compared with persons with a lower level of education (Strandell \& Wolff, 2018).

\section{Conclusions}

Employees and future employees need to take into account that work arrangements are much more diverse and that working in a standardized form may no longer be dominant in the future. Working from home, from other continents, with multiple employers at once, project work, just for a limited time, using online platforms etc. are increasingly common. Employees must also invest in the development of specific skills that will be harder to be replaced by artificial intelligence such as social skills, creative thinking, cross-cultural competencies, etc. In the digital era with hyper connectivity and machine/human interactions, employees need to constantly keep up to date with their knowledge and develop new skills related to using new technology. 


\section{REFERENCES}

Acemoglu, D., \& Autor, D. (2011). Skills, tasks and technologies: Implications for employment and earnings. Handbook of Labor Economics, Vol. 4, Issue 16082, 1043-1171. doi:10.1016/s0169-7218(11)02410-5.

Aleksynska, M., \& Muller, A. (2015). Nothing more permanent than temporary? Understanding fixed-term contracts. Policy Brief, No. 6, Geneva: International Labor Organization.

Allen, R. C. (2011). Why the industrial revolution was British: Commerce, induced invention, and the scientific revolution. The Economic History Review, Vol. 64, Issue 2, 357-384.

Alterman, T., Luckhaupt, S. E., Dahlhamer, J. M., Ward, B. W., \& Calvert, G. M. (2013). Prevalence rates of work organization characteristics among workers in the U.S.: data from the 2010 National Health Interview Survey. American Journal of Industrial Medicine, Vol. 56, Issue 6, 647-659. doi:10.1002/ajim.22108.

Baldwin, R. (2019). The globotics upheaval. Globalization, robotics and the future of work. New York, USA: Oxford University Press.

Brabham, D. C. (2008). Crowdsourcing as a model for problem solving. Convergence. The International Journal of Research into New Media Technologies, Vol. 14, Issue 1, 75-90. doi:10.1177/1354856507084420.

Christian, J., Porter, L. W., \& Moffitt, G. (2006). Workplace diversity and group relations: An overview. Group Processes \& Intergroup Relations, Vol. 9, Issue 4, 459-466.

Datta, N., Giupponi, G., \& Machin, S. (2018). Zero hours contracts and labor market policy. Paper for Economic Policy $68^{\text {th }}$ Panel Meeting, Vienna.

Davies, A., Fidler, D., Gorbis, M. (2011). Future work skills 2020. Palo Alto: Institute for the Future.

Doll, W., \& Vonderembse, M. (1991). The evolution of manufacturing systems: Towards the post-industrial enterprise. Omega, Vol. 19, Issue 5, 401-411. doi:10.1016/03050483(91)90057-z.

Eichhorst, E., \& Tobsch, V. (2013). Has atypical work become typical in Germany?. IZA Institute of Labor Economics, Discussion Paper, No, 7609.

Eurofound. (2015). New forms of employment. Luxembourg: Publications Office of the European Union.

Farina, E., Green, C., \& McVicar, D. (2019). Zero hours contracts and their growth. IZA Institute of Labor Economics, Discussion Paper, No. 12291, available at: http://ftp.iza.org, accessed on 05 September 2019.

Frey, C. B., \& Osborne, M. A. (2017). The future of employment: How susceptible are jobs to computerisation?. Technological Forecasting and Social Change, Vol. 114, 254-280. doi:10.1016/j.techfore.2016.08.019.

International Labour Organization. (2016). Challenges and opportunities of teleworking for workers and employers in the ICTS and financial services sectors, available at: https://www.ilo.org, accessed on 18 September 2019.

Jarrahi, M. H. (2018). Artificial intelligence and the future of work: Human-AI symbiosis in organizational decision making. Business Horizons, Vol. 61, Issue 4, 577-586. doi:10.1016/j.bushor.2018.03.007.

Katz, L., \& Krueger, A. (2016). The Rise and nature of alternative work arrangements in the United States, 1995-2015. The National Bureau of Economic Research. Working Paper, No. 22667. 
Katz, L., \& Krueger, A. (2017). The role of unemployment in the rise in alternative work arrangements. American Economic Review, Vol. 107, Issue 5, 388-392.

Lee, M., Yun, J. J., Pyka, A., Won, D., Kodama, F., Schiuma, G., Park, H. S., Jeon, J., Park, K. B., Jung, K. H., Yan, M.-R., Lee, S. Y., \& Zhao, X. (2018). How to respond to the fourth industrial revolution, or the second information technology revolution? Dynamic new combinations between technology, market, and society through open innovation. Journal of Open Innovation: Technology, Market, and Complexity, Vol. 4, Issue 21, 1-24. doi:10.3390/joitmc4030021.

Leighton, P., \& Brown, D. (2013). Future working: The rise of Europe's independent professionals (iPros). London: European Forum of Independent Professionals.

Mazur, B. (2010). Cultural diversity in organisational theory and practice. Journal of Intercultural Management, Vol. 2, Issue 2, 5-15.

Messenger, J. C., \& Gschwind, L. (2016). Three generations of telework: New ICTs and the (R)evolution from home office to virtual office. New Technology, Work and Employment, Vol. 31, Issue 3, 195-208. doi:10.1111/ntwe.12073.

Organization for Economic Cooperation and Development. (2010). Gender brief, available at: https://www.oecd.org, accessed on 18 September 2019.

Park, S.-C. (2017). The Fourth Industrial Revolution and implications for innovative cluster policies. AI \& SOCIETY, Vol. 33, Issue 3, 433-445. Doi:10.1007/s00146-017-0777-5.

Phillips, D. R., \& Siu, O. (2012). Global aging and aging workers. In Hedge, J. W., \& Borman, W. W. C. (Eds.), The oxford handbook of work and aging (pp. 11-32). New York, NY: Oxford University Press.

Prasad, P., Pringle, J. K., \& Konrad, A. M. (2006). Examining the contours of workplace diversity. In Konrad, A. M., Prasad, P., \& Pringle, J. K. (Eds.) Handbook of work diversity (pp. 1-22). London: Sage.

Saxton, G. D., Oh, O., \& Kishore, R. (2013). Rules of crowdsourcing: models, issues, and systems of control. Information Systems Management, Vol. 30, Issue 1, 2-20. doi:10.1080/10580530.2013.739883.

Schwab, K. (2016). The fourth industrial revolution. Geneva: World Economic Forum.

Strandell, H., \& Wolff, P. (2018). Globalisation patterns in trade and investment introductory chapters. Statistics explained, available at: http://ec.europa.eu/eurostat/ statisticsexplained/, accessed on 3 September 2019.

United Nations. (2017). World population prospects: The 2017 revision, key findings and advance tables. Working Paper, No. ESA/P/WP/248.

Wang, D., Khosla, A., Gargeya, R., Irshad, H., \& Beck, A. H. (2016). Deep learning for identifying metastatic breast cancer, available at: https://arxiv.org/pdf/1606.05718, accessed on 10 October 2019.

Wobbe, W. (2016). Digitalisation of work and the social impact of the platform economy. In Durward, D., Blohm, I., \& Leimeister, J. (Eds). Principal forms of crowdsourcing and crowd work (pp 13-36). Brussels: Foundation for European Progressive Studies.

World Economic Forum. (2016). The future of jobs employment, skills and workforce strategy for the Fourth Industrial Revolution, available at: http://www3.weforum.org/ docs/WEF Future of Jobs.pdf, accessed on 03 October 2019.

World Economic Forum. (2018). The future of jobs report 2018, available at: http://www3.weforum.org/docs/WEF_Future of Jobs_2018.pdf, accessed on 07 October 2019. 